\title{
BRONCHOALVEOLAR INTERLEUKIN-1 BETA: A MARKER OF BACTERIAL BURDEN IN CRITCALLY ILL CHILDREN WITH NOSOCOMIAL PNEUMONIA
}

\author{
D. Dmytriiev, O. Katilov, K. Dmytriieva
}

Vinnitsa National Medical University, Vinnitsa, Ukraine

Objective: To assess the relationship between concentrations of bronchoalveolar cytokines and bacterial burden in critically ill children with a presumptive diagnosis of nosocomial pneumonia.

Patients: According to the time course of nosocomial pneumonia at the time of study with bronchoalveolar lavage, 62 critically ill children with nosocomial pneumonia

Interventions: According to the time course of ventilator-associated pneumonia at the time of study with bronchoalveolar lavage, 62 children were divided into two subgroups: referral $(n=32)$, and treated $(n=30)$ nosocomial pneumonia. Bronchoalveolar lavage was performed in the most abnormal area on chest radiograph by fiberoptic bronchoscope. The concentrations of bronchoalveolar lavage cytokines.

Measurement and main results: 34 patients had a positive bacterial culture (bronchoalveolar lavage $>$ or $=$ 10 colony-forming units $/ \mathrm{mL}$ ), and made up $82 \%$ of pathogens recovered at high concentrations. The concentrations of bronchoalveolar lavage interleukin-1 beta were $204.2+/-15.7$ and $38.2+/-12.6 \mathrm{pg} / \mathrm{mL}$ (mean $+/-\mathrm{se})$ in the children with positive and negative bacterial culture, respectively $(\mathrm{p}<.001)$. Bronchoalveolar lavage interleukin- 1 beta was significantly higher in the children with a high bacterial burden $(\mathrm{p}<0.001)$, with mixed bacterial infection $(\mathrm{p}<0.001)$, and with nosocomial pneumonia $(\mathrm{p}<0.001)$, compared with values in patients without these features.

Conclusions: Since the concentration of bronchoalveolar lavage interleukin-1 beta was correlated with bacterial burden in the alveoli, it may be a marker for progressive and ongoing inflammation in critically ill children. 